\title{
Vasculogenesis in Diabetes-Associated Diseases: Unraveling the Diabetic Paradox
}

\author{
Carla Costa \\ Faculty of Medicine of the University of Porto, Departament of Biochemistry (U38-FCT) \\ Department of Experimental Biology \\ Portugal
}

\section{Introduction}

During several decades it was thought that in the adult, vascular growth and remodelling was exclusively dependent on the activation of angiogenesis, being the process of vasculogenesis restricted to embryonic life (Risau \& Flamme, 1995; Risau, 1997). This long-lasting belief has come to an end in the late nineties, with the isolation from adult peripheral blood (PB) of angioblast-like circulating Endothelial Progenitor Cells (EPCs) (Asahara et al., 1997). The discovery of bone marrow (BM)-derived EPCs with angioblastic morphological and functional properties was a landmark in vascular biology that forever has changed the concept of neovascularization. Numerous studies have demonstrated that EPCs residing in the BM could be mobilized to the peripheral circulation, migrate to neoangiogenic sites and partake in vivo in the pathophysiological development of vascular networks, by differentiating into functional, mature endothelial cells (ECs) (Asahara et al., 1999a, 1999b; Goon et al., 2007; Grant et al., 2002; Lyden et al., 2001; Takahashi et al., 1999). However, much controversy has accompanied this field over time, particularly regarding the phenotypic characterization of EPCs. In fact, this cell population does not have specific cell surface markers, sharing a diversity of membrane receptors with other BM-derived cells (Hristov et al., 2003; Peichev et al., 2000). Additionally, several subsets of EPCs have been identified and together with other lineages of precursor cells were found to be differentially recruited to neovascular foci contributing synergistically to vasculogenic neoformation (Gulati et al., 2003; Hur et al., 2004; Lyden et al., 2001; Yoder et al., 2007; Yoon et al., 2005a). Since their identification, an increasing body of evidence has definitely revealed the important properties and roles played by EPCs in several vascularrelated diseases, such as peripheral vascular disease (Asahara et al., 1999a, 1999b; Takahashi et al., 1999), tumor neovascularisation (Asahara et al., 1999a, 1999b; Lyden et al., 2001) and vascular complications associated to diabetes (Goon et al., 2007; Grant et al., 2002; Egan et al., 2008; Fadini et al., 2005). The metabolic alterations present in diabetic individuals are known to profoundly affect vascular biology, being responsible for the impairment of macro- and microvascular beds (Fadini et al., 2006a; Werner et al., 2005). Diabetes associated vascular complications involve distinct modifications in neovascular formation, which is reduced in ischemic heart and limbs and increased in the retina, defining the diabetic paradox (Ciulla et al., 2003). The vasculogenic process seems to play a central dual role in this paradoxal puzzle: systemically, diabetes-associated hyperglycemia, insulin resistance, hypertension and oxidative stress, can simultaneoulsy 
injure the endothelium and deliteriously affect EPCs biological functions, impairing efficient systemic vascular repair and promoting peripheral vasculopathy (Povsic \& Goldschmidt-Clermont, 2008); locally in the retina, the specific microenvironment may contribute to the local recruitment of EPCs, promoting increased vessel growth (Goon et al., 2007; Grant et al., 2002). Although still under investigation, these divergent features seem related to a differential regulation of neovascular mechanisms, which responde differently to ischemia-induced depletion of angiogenic factors in systemic conditions, or to the local induction of vascular growth factors in the diabetic retina (Duh \& Aiello, 1999). Due to the growing importance of vasculogenesis in diabetic vascular complications, interventions differentially modulating EPCs levels/functions may be regarded as therapeutic strategies. Systemically, vasculoprotective agents provided with beneficial cardiovascular effects, have showed to improve endothelium-dependent vascular function, by restoring EPCs properties and actions (Liang et al., 2009). Local delivery of anti-angiogenic drugs to the retina may have positive effects by hampering EPCs recruitment in proliferative diabetic retinopathy (PDR) (Chung et al., 2011). However, one might not neglect that diabetic patients frequently display both neovascular peripheral decrease and retinal increase of vessel growth. So, important questions are raised regarding the therapeutic use of EPCs in the promotion of periptheral vascularization and the impairment of EPCs-induced retinal neovascular formation and increased ischemia. Several issues need to be addressed in order to optimize the therapeutic use of EPCs and to get further information on the putative harmful side effects. Future research is mandatory in order to elucidate the complex molecular mechanisms governing the diabetic-vasculogenic paradigm, bringing novel insights into the safety on the therapeutic modulation of EPCs in diabetes vascular disorders.

\section{Endothelial progenitor cells (EPCs) and postnatal vasculogenesis}

Vasculogenesis and angiogenesis are the fundamental processes by which new blood vessels are formed. Vasculogenesis is defined as the differentiation of EPCs or angioblasts into ECs and the de novo formation of a primitive vascular network, whereas angiogenesis is the growth of new capillaries from pre-existing blood vessels (Risau \& Flamme, 1995; Risau, 1997). In the embryo, blood vessels form through both vasculogenesis and angiogenesis. Vasculogenesis occurs during early embryonic development and mediates the de novo vessel formation from angioblasts of mesodermal origin, which differentiate into mature ECs assembling into a primary capillary plexus (Risau \& Flamme, 1995). Subsequently, this primitive vascular network expands by angiogenesis, where new blood vessels arise from the proliferation and migration of the pre-existing ECs (Folkman, 1984; Risau, 1997). During several decades it was thought that in the adult, vascular growth and remodelling was exclusively dependent on the activation of angiogenesis, and that the process of vasculogenesis was restricted to embryonic life. This prevailing dogma has come to an end over a decade ago, with the identification of circulating BM-derived EPCs in 1997 by Asahara and collaborators, which have isolated a population of angioblast-like CD34+ circulating EPCs from adult PB. In in vitro cultures, these cells presented an increased proliferation rate and exhibited endothelial morphological and functional properties (Asahara et al., 1997). However, this pioneering work was criticized and the true identity of the putative EPCs was questioned. In fact, besides the functional characteristics of these progenitor cells, namely their high proliferative capacity, this report did not provide any additional information regarding other specific functional characteristics. Additionaly, in 
Asahara's work the CD34 antigen was used to select EPCs, however the authors did not present a defined set of other phenotypic markers that could unambiguously identify this cell population allowing their sole isolation. In fact, CD34 is also expressed in sub-groups of hematopoietic stem/progenitor cells and mature ECs and does not specifically discriminate EPCs. Nevertheless, the work of Asahara et al. set a landmark in the field of vascular biology, for being the first to suggest that vasculogenesis could occur during adult life. Besides the controversy, after this initial report, a boom of novel studies corroborated Asahara's hypothesis, presenting novel evidence for the existence of postnatal EPCs and their functional role in pathophysiological neovascular processes. Several reports demonstrated that a population of EPCs residing in the BM could be mobilized to the peripheral circulation, migrate to neoangiogenic foci and partake in vivo in the development of vascular networks, by differentiating into functional matured ECs and incorportating the vasculature (Asahara et al., 1999a, 1999b; Lyden et al., 2001; Shi et al., 1998). EPCs mobilization from the $\mathrm{BM}$ and homing to neovascular foci occurred in response of progenitor cells to specific angiogenic stimuli. The initial steps in mobilization involved the activation of matrix metalloproteinase (MMP)-9, which catalyses the conversion of membrane-bound Kit ligand to soluble Kit ligand. The subsequent cKit-positive progenitor cells are disengaged and can then move from the osteoblastic to the vascular zone of the BM. This process is enhanced by elevated levels of the chemokines Stromal Derived Factor (SDF)-1 and Vascular Endothelial Growth Factor (VEGF) (Heissig et al., 2002) and appears to be endothelial Nitric Oxide (eNO) dependent (Aicher et al., 2003). Increased eNO levels stimulate the passage of EPCs through BM sinusoidal endothelium and their entrance in the blood stream, where they are further recruited to neoangiogenic foci (Aicher at el., 2003, 2005).

\section{EPCs phenotypic and functional properties}

Since their identification, the phenotypic characterization of EPCs has emerged a major setback in the field. Their isolation, identification and characterization were mostly hampered by the lack of EPCs-specific surface markers. Over time some consensus has apparently been reached and EPCs were considered to be the cell population characterized by the concomitant expression of: the early hematopoietic stem cell markers CD34 and CD133 (former AC133) and VEGF receptor-2 (VEGFR-2) (Hristov et al., 2003; Peichev et al., 2000). However, it has been suggested that human CD34+CD133+VEGFR2+ cells comprise a population of cells that are not only EPCs, but distinct primitive hematopoietic progenitors, which also express markers such as CD45 and are devoid of vessel formation capabilities (Case et al., 2007; Timmermans et al., 2007). Other findings have demonstrated the existence of novel subsets of progenitor cells with an involvement in vascular repair. It was reported the presence in PB of a stem cell population which lack the CD34 antigen and is able to differentiate into CD34+CD133+ EPCs, and acquire a more mature endothelial phenotype (Friedrich et al., 2006). Additionally, other populations with endothelial repair capabilities which express additional cell surface markers, including the receptor for SDF-1, the chemokine (C-X-C motif) receptor (CXCR)-4 have also been identified (Egan et al., 2008). The characterization of these different subpopulations of EPCs is due to the different methodology used for cell isolation. To date, there are three main techniques that have been used to select, identify and characterize EPCs (Hirschi et al., 2008; Yoder, 2009). The cell types isolated using the different protocols are not phenotypically similar and as such, their 
potential to influence neovascularization and/or vascular repair may vary. Consequently, this may offer an explanation as to the differences observed amongst similar studies which presented divergent results.

\subsection{Methods for EPCs isolation and characterization 3.1.1 Culture of isolated mononuclear cells}

This method involves the isolation of mononuclear cells from PB or BM using density gradient centrifugation and the platting of these cells on fibronectin-coated substracts and cultured in medium supplemented with endothelial growth factors. Approximately 3 days later, non-adherent cells are removed from the culture and fresh media is added to the remaining cells which continue to be cultured and futher analysed. These spindle shapedadherent cells express EC markers and functional qualities, such as endocytosis and acetylated low-density lipoprotein (LDL) uptake. However, unlike progenitor cells they display low proliferative capacity, cannot form EC tube-like structures in an in vitro angiogenesis assay model, but do display panleukocyte and monocytic/macrophage markers, such as CD14 and CD45 (Rehman et al., 2003; Zhang et al., 2006, 2007). In support of this finding, previous data showed that monocytes have high affinity for fibronectin, and that $90 \%$ of cells from PB samples which adhere to coated dishes are of monocytic origin (Freundlich \& Avdalovic, 1983). Moreover, a recent study by Prokopi et al. suggested how these putative EPCs may acquire EC markers. According to their data, the method used for mononuclear cell isolation from PB leads to the contamination of cells with platelets, which also express endothelial markers such as CD31 and von Willebrand factor (vWF) (Prokopi et al., 2009). During a 7 day mononuclear cell culture, the platelets are degraded into microparticles, vesicles which retain specific antigens from the cell of origin. So, adherent day 1 mononuclear cells presented as CD31 negative, but by day 7 expressed the CD31 antigen, along with platelet-specific markers, following the uptake of degraded platelet microparticles and a transfer of cell antigens. Additionally, depletion of platelet microparticles from the EPCs culture media also removed the angiogenic properties often attributed to EPC culture medium, indicating that this in vitro property may be dependent on initial platelet presence following mononuclear cell isolation (Kirton \& Xu, 2010; Rehman et al., 2003; Urbich et al., 2005).

\subsubsection{Fluorescence activated cell sorting (FACS) and in vitro culture}

One of the most currently used methods for EPCs separation, involves cell labelling with antigen specific antibodies and FACS analysis. This was the technique used by Asahara et al. in their pioneering work to isolate CD34+ mononuclear cells (Asahara et al., 1997). Since as aforementioned, CD34 does not selectively discriminate EPCs, following studies also included the use of CD133 combined with CD34 and VEGFR-2 (Peichev et al., 2000), to ensure that only progenitor cells were isolated as apposed to circulating ECs that have detached from the vessel wall (Blann \& Pretorius, 2006; Ingram et al., 2005). These cells were cultured for 2 days and non-adherent cells re-plated for further 14 days, giving similar clustered colonies. Upon differentiating into mature ECs, EPCs lose the expression of CD133 and start exhibiting classical EC morphology and features, such as the expression of the endothelial markers vWF and vascular endothelial cadherin (VE-cadherin) and the capacity to uptake acetylated LDL (Peichev et al., 2000; Shi et al., 1998). Several subsequent studies successfully isolated this cell type from adult PB, umbilical cord blood and fetal liver, using 
a combination of these three markers (Timmermans et al., 2009). However, further controversy has arised since, it was reported that CD34+CD133+VEGFR2+ cells comprise a mixed population of EPCs and primitive hematopoietic progenitors, which express also CD45 and also lack the ability to form vessel-like structures (Case et al., 2007; Timmermans et al., 2007).

\subsubsection{In vitro colony forming cell assays}

Using this technique independent groups have shown that in adult PB mononuclear cells there are two distinct EPCs populations, which form in vitro Early Outgrowth Colonies (EOCs) and Late Outgrowth Colonies (LOCs) (Gulati et al., 2003; Hur et al., 2004). Additional studies have used different designations for these cell types: EOCs were also named early EPCs (eEPCs) and LOCs are also known as Outgrowth Endothelial Cells (OECs) (Medina et al., 2010, Yoon et al., 2005a) Although the biology of these endothelial progenitor-like cells is still under investigation, they seem to present different phenotypes, surface antigens and display diverse vasculogenic features in vitro. EOCs and LOCs are primarily characterized based on their morphology and chronology of appearance following in vitro culture. EOCs appear in culture within 7 days, emanating from a central cluster of cells, exhibiting spindle-shaped morphology and having a peak growth at 2-3 weeks after which they cannot be further expanded (Gulati et al., 2003; Hur et al., 2004). LOCs generally appear after 3 weeks and exhibit a "classic endothelial" phenotype, having an increased expansion potential. LOCs seem more capable of in vitro morphogenesis into capillary tubes, the best approximate true definition of an EPC, a competent progenitor cell whose terminally differentiated progeny are mature ECs (Gulati et al., 2003; Hur et al., 2004; Yoder et al., 2007). This capillary-forming capacity is minimal or nonexistent within EOCs, which are thought to have a paracrine role by supporting LOCs differentiation and capillary formation, through the release of proangiogenic molecules and by inducing the activation of MMPs (Gulati et al., 2003; Hur et al., 2004; Yoon et al., 2005a). Phenotypically, EOCs additionally express the monocyte/macrophage marker CD14, which is absent among mature LOCs, and both populations may concomitantly express CD34 and VEGFR-2 (Yoon et al., 2005a). However, besides the reported alterations in phenotypic markers and the dissimilar biological properties, there was a lack of information regarding molecular differences between EOCs and LOCs. Recently, a study has provided a detailed molecular fingerprint of these two EPC subtypes, designated in this report by eEPCs and OECs. Medina and collaborators have shown that eEPCs and OECs have strikingly different gene/protein expression signatures (Medina et al., 2010). As evaluated by microarrays, many highly expressed transcripts in eEPCs were hematopoietic specific, including the Runt-related transcription factor (RUNX1) and the protein tyrosine kinase LYN; and with links to immunity and inflammation (Toll-Like Receptors, TLRs; CD14; Human Leukocyte Antigens, HLAs). On the other hand, OECs presented several highly expressed transcripts involved in vascular development and angiogenesis-related signaling pathways, such as the receptor tyrosine kinase Tie2, eNOS and Ephrins. Similarly, proteomic analysis revealed that $90 \%$ of spots identified by 2D gel electrophoresis analysis were common between OECs and endothelial cells while eEPCs shared 77\% with monocytes. This study provided evidence that eEPCs are hematopoietic cells with a molecular phenotype linked to monocytes; whereas OECs exhibit commitment to the endothelial lineage, corroborating at the molecular level all the previous studies that have phenotypically 
characterized these cell populations. These findings indicate that OECs are the subtype with vasculogenic capability and that functionally integrates neovascular foci, and it should be an attractive cell candidate for inducing therapeutic angiogenesis.

Overall, these reports indicate that EPCs represent a heterogeneous population of cells, some of monocytic nature and others with a pro-angiogenic potential. Depending on the study model, cell isolation method and cell subtype used, the pro-angiogenic effects are a consequence of the direct vascular integration, the paracrine release of growth factors and cytokines, or the complex interactions with other cellular components like monocytes or platelets. Nonetheless, most of the reports involving in vitro and in vivo EPCs studies do not usually make a distinction between EOCs (eEPCs) and LOCs (OECs), analyzing both populations as a whole. As aforementioned, this may explain divergences observed amongst similar studies.

\section{Vasculogenesis and in vivo neovascular formation in pathophysiological processes}

Studies carried on experimental models have shown that postnatal vasculogenesis could take place under certain physiological and pathological settings. Further, it was also suggested that other BM-derived hematopoietic stem/myeloid progenitor cells, named as accessory cells, could be co-recruited to neoangiogenesis foci, and support vascular growth in a paracrine fashion through the release of pro-angiogenic factors or by contributing to extracellular matrix remodeling (De Palma et al., 2005; Fang \& Salven, 2011; Grunewald et al., 2006; Kaplan et al., 2005; Lyden et al., 2001; Takakura, 2006). Due to the relevant role of neovascularization for tumor growth and metastization, several pre-clinical studies evaluated EPCs functions and their contribution for malignant development (Asahara et al., 1999a, 1999b; Lyden et al., 2001). Additionally and corroborating experimental data, it was also reported that a percentage of BM-derived EPCs can integrate human tumour-associated neovasculature (Peters et al., 2005). Nonethess, despite all these evidence Purhonen et al. have suggested that BM-derived circulating EPCs do not contribute to vascular endothelium and are not needed for tumor development, raising novel controversy in the field (Purhonen et al., 2008). Besides tumor neovascular formation, further studies confirmed that EPCs play also a role in: vascular homeostasis and repair (Asahara et al., 1999a; Kirton \& Xu, 2010; Shantsila et al., 2007), wound healing (Asahara et al., 1999b), bone regeneration (Matsumoto et al. 2008), myocardial infaction (Porto et al., 2011; Shintani et al., 2001), limb ischemia (Asahara et al., 1999a, 1999b; Takahashi et al., 1999), burn individuals and escharectomy (Foresta et al., 2011; Gill et al., 2001) and vascular complications associated to diabetes (Goon et al., 2007; Grant et al., 2002; Egan et al., 2008; Fadini et al., 2005).

\section{Vasculogenesis and the diabetic paradox}

Diabetes mellitus (DM) is a common costly chronic disease and its incidence is rapidly increasing worldwide. Once considered primarily as a risk factor for heart disease, diabetes has now become a high profile public health concern in its own right, due to the escalating epidemic of diabetes in older people, and the emergence of type 2 DM (T2DM) in children. In fact, individuals with T2DM account for most of this augmentation in the general population. An important part of this rise is attributed to changing living conditions, including overweight and obesity, sedentary behaviour, and unhealthy lifestyle (Perkins, 
2004; Zimmet et al., 2001). Vascular complications in T2DM are a significant cause of human morbidity and mortality, by affecting multiple organs, in particular the cardiovascular system, through the promotion of atherosclerosis (Haffner et al., 1998; Nakagami et al., 2005; Werner et al., 2005). Diabetic vascular alterations in different organs occur by distinct modifications in neovascular formation, which is decreased in systemic cardiovascular disease (CVD) and increased in DR. This diabetic paradox has been attributed to the differential regulation of neovascular mechanisms, which responde differently to ischemia in diabetic conditions (Duh \& Aiello, 1999). The vasculogenic process seems to play a central dual role in this paradoxal puzzle: by one hand diabetes-associated hyperglycemia, insulin resistance, hypertension and oxidative stress, can simultaneoulsy injure the endothelium and deliteriously affect EPCs functions, thus preventing efficient systemic vascular repair, favoring the development of peripheral vasculopathy (Povsic \& Goldschmidt-Clermont, 2008); on the other hand the specific retinal millieu may promote the local recruitment of EPCs, contributing to increased vessel growth in PDR (Goon et al., 2007; Grant et al., 2002). Althought the complex mechanisms governing this diabetic-vasculogenic paradox are still under investigation, novel evidence links alterations in EPCs biological functions to diabetic vascular complications, and will be further discussed.

\section{Diabetic vasculopathy and altered vasculogenesis}

Diabetes is characterized by a systemic pro-inflammatory state and generalized endothelial dysfunction (EDys). EDys ultimately represents the unbalance between endothelium injury and the endogenous capacity for endothelial repair (Costa et al., 2007). Compelling evidence suggested that hyperglycemia, insulin resistance, hypertension and oxidative stress, simultaneously promote endothelial damage and deliteriously affect EPCs functions, thus preventing efficient vascular repair and favoring the development of atherosclerotic lesions (Madonna \& De Caterina, 2011; Povsic \& Goldschmidt-Clermont, 2008). Amongst all these risk factors, increased glycemic levels and excessive oxidative stress seem to be the major causal factors underlying both endothelial injury and vasculogenic impairment (Callaghan et al., 2005). Nonetheless, the complex interplay between all the aforementioned conditions is thought to sinergistically decrease endothelial regeneration by altering EPCs biological activities, such as: reducing EPCs migration (Kränkel et al., 2005; Vasa et al., 2001); impairing their mobilization (Fadini et al., 2006b; Gallagher et al., 2007; Kang et al., 2009; Yao et al., 2006); promoting premature senescence (Higashi et al., 2002); inhibiting integrative and morphogenic capacities (defective adhesion, colony-forming ability and tubulization) (Fadini et al., 2006a; Tepper et al., 2002) and inducing EPCs apoptosis (Chen et al., 2010; Shen et al., 2010). These alterations on EPCs features have been associated with deficient endogenous re-endothelialization/neovascularization, being a potential indicator of diabetic CVD severity (Egan et al., 2008; Fadini et al., 2005; 2006b). In conjunction with deficient EPCs functions, the production of chemotactic/angiogenic factors is inhibited in diabetic peripheral ischemic tissues; contributing both to poor collateral formation and insufficient perfusion. It has been shown that the expression of angiogenic factors such as, VEGF and Hypoxia-Inducible Factor (HIF)- $1 \alpha$ are reduced in the heart of diabetic patients during acute coronary syndromes (Marfella et al., 2004). Recently, it was also demonstrated that following the onset of acute myocardial infarction in T2DM patients, the numbers of CD133+ progenitor cells are reduced and their chemotactic responsiveness attenuated (Vöö et al., 2009). Both the defective expression of angiogenic factors and the dysfunction in EPCs 
account for the delayed post-ischemic vascular healing and myocardial recovery in patients with DM. Diabetic cardiomyopathy is also characterized by an early and progressive decline in myocardial VEGF expression and reduced circulating EPCs, which contributes to diminished capillary density, decreased myocardial perfusion and impaired contractility (Yoon et al., 2005b). A significant decline in circulating EPCs was also reported in diabetic patients with peripheral arterial disease (PAD), particularly in individuals with ischemic foot lesions. EPCs levels correlated with the ankle-brachial index, the most objective diagnostic and prognostic test for lower extremity arterial disease. It was also demonstrated that decreased EPCs closely correlated with the severity of both carotid and lower limb atherosclerosis. Higher degrees of carotid stenosis, as well as, worse stages of leg claudication and ischemic lesions, were associated with lower levels of EPCs. This suggested that EPCs counts could be considered a valuable marker for atherosclerotic involvement (Fadini et al., 2005). Additionally, EPCs isolated from diabetic patients with PAD exhibited poor endothelial differentiation capacity, impaired proliferation and deficient adhesion to mature endothelium (Fadini et al., 2006a; 2006c). Recently, a study evaluated circulating levels of CD34-CD133+VEGFR-2+ EPCs in diabetic patients with CVD, revealing a decrease in this subpopulation caused by diabetes-induced apoptosis (Jung et al., 2010). Similarly, it was also proposed that a subset of CXCR-4+ progenitor cells with vascular repair capability, were decreased in the PB of T2DM patients (Egan et al., 2008). In ischemic conditions, reduced levels of CXCR-4+ precursors may responde poorly to SDF-1, preventing their efficient mobilization and recruitment from the BM niche to ischemic sites. In addition, it seems relevant to mention novel data disclosing the effects of hyperglycemia in EPCs in intrauterine life. Interestingly, the exposure to high glucose levels in a diabetic intrauterine environment was shown to diminish the clonogenic potential of neonatal EPCs, providing a new insight into the long-term cardiovascular complications observed in newborns of diabetic pregnancies (Ingram et al., 2008). Since it was reported that hyperglycemia, insulin resistance, hypertension and oxidative stress, are key factors on promoting endothelial damage and by altering EPCs functions, it will be further discussed how these conditions deleteriously affect vasculogenic events associated to peripheral vasculopathy (Madonna \& De Caterina, 2011; Povsic \& Goldschmidt-Clermont, 2008)

\subsection{Hyperglycemia}

Hyperglycemia is one of the major causal factors implicated in the development of vascular alterations (Aronson, 2008). High glucose levels are involved in the generation of advanced glycation end products (AGEs), which accumulate in the vessel wall, and by interacting with its receptors (RAGE) induce oxidative stress, increase inflammation and promote EDys (Jandeleit-Dahm \& Cooper, 2008). Hyperglycemia is thought to maintain EDys conditions by directly impairing most EPCs-driven functional capabilities. Hyperglycemia was demonstrated to: decrease EPCs migration and integrative capacities (Kränkel et al., 2005); shift their differentiation into a pro-inflammatory phenotype (Loomans et al., 2009); reduce EPCs mobilization (Gallagher et al., 2007); accelerate the onset of progenitor cell senescence (Chen et al., 2007); induce apoptotsis (Chen et al., 2010); inhibit EPCs colony-forming ability; decrease the number and proliferation of both early and late EPCs (EOCs and LOCs) and to impair the migration and vasculogenesis activities of LOCs, the subtype with vasculogenic-associated morphogenesis capability (Chen et al., 2007). Decreased vascular progenitor cells migration and inhibition of functional incorporation into tubular structures, were suggested to occur through 
hyperglycemia-induced decrease in NO production and MMP-9 activity (Kränkel et al., 2005). Reduced mobilization of EPCs was showed to occur due to modifications in eNOS phosphorylation and activation status within the BM microenvironment, unabling efficient EPCs release from the marrow niche to the peripheral circulation (Gallagher et al., 2007; Ingram et al., 2008). Hyperglycemia-induced EPCs senescence was demonstrated to take place through multiple mechanisms such as, by promoting telomere shortening, and alterations in the p38 MAPK and NO-mediated pathways (Chen et al., 2007; Ingram et al., 2008; Kuki et al., 2006). Additionally, a novel molecular link between high glucose levels and EPCs-increased senescence has been unveilled, as it was demonstrated that the Sirtuin 1 (SIRT1) gene, which regulates cell cycle, premature senescence and apoptosis, is downregulated in EPCs. SIRT1 low expression levels impair the important cascade of intracellular events, culminating with EPCs early senescence (Balestrieri et al., 2008a). Highlighting the crucial effects of high glicemic levels, it was also reported that the number of EPCs in T2DM was significantly decreased as compared with healthy controls. Additionally, an inverse correlation between EPCs numbers, plasma glucose and glycated hemoglobin (HbA1C) was found. Further, the number and function of EPCs in patients with good glycemic control were recovered compared with those with poor glycemic control. When glucose was supplemented to in vitro cultures, there was a negative effect on the proliferation and viability of EPCs, in a dose-dependent manner, whereas the enhancement of apoptosis was observed (Churdchomjan et al., 2010). All these deleterious effects were reported to occur due to a direct effect of elevated glucose levels on EPCs (Chen et al., 2007), however it was also suggested that hyperglycemia may promote EPCs dysfunction indirectly through the induction of Reactive Oxygen Species (ROS) overproduction and increased oxidative stress (Callaghan et al,. 2005). Moreover, antidiabetic treatments were reported to improve the re-endothelialization capacity of EPCs from diabetic individuals (Gensch et al., 2007).

\subsection{Insulin resistance (IR)}

Approximately $80 \%$ of all T2DM coexist with IR (Zimmet et al.; 2001). Several studies have proposed that IR may affect unfavourably the balance between endothelial injury and endogenous repair, promoting EDys and contributing to premature atherosclerosis (Dandona et al., 2003; 2004). Apparently, IR aids EDys perpectuation (Kim et al., 2006) by modulating vasculogenesis-associated EPCs capability of effectively promoting endothelium regeneration. Althought the direct mechanisms by which IR alters EPCs functions are still unclear, it was recently suggested that the chronic inflammatory environment present in T2DM leads to insulin signaling defects in EPCs, thereby reducing their survival (Desouza et al., 2011). Additionally, it was also reported that after arterial injury in hemizygous knockout mice for the insulin receptor (IRKO), EPCs activities were altered and endothelial regeneration delayed. This defective endothelial repair could be normalized by transfusion of progenitor cells from insulin-sensitive animals, but not from insulin-resistant animals (Kahn et al., 2011). However, it is thought that EPCs biological modifications are mostly affected by IR in an indirect fashion, through the increase in ROS and also by the activation of pro-inflammatory cytokines (Cubbon et al., 2007; 2009; Houstis et al., 2006). In fact, IR states are closely linked to the increased production of ROS, which is a characteristic feature of IR and thought to play a causal role in its development (Houstis et al., 2006). The deleterious effects of oxidative stress in EPCs biological characteristics have been established and will be contemplated in section 6.4. Although further direct cause-effect between IR and EPCs alterations is currently under 
investigation, it has been shown that treatments with insulin sensitizing drugs may improve EPCs functional parameters, independently of glycemic levels and/or redox status (Schoonjans \& Auwerx, 2001). Nonetheless, further studies are necessary to clarify the molecular links between IR and vasculogenic impairment.

\subsection{Hypertension}

High blood pressure levels are associated with significant mechanical endothelial injury and dysfunction (Spieker et al., 2000). Disruption of endothelial homeostasis in hypertensive patients is thought to worsen their cardiovascular prognosis (Perticone et al., 2001) and contribute to increased blood pressure levels (Schiffrin, 2001). Alterations in vasculogenesisrelated mechanisms have been associated to hypertension-induced EDys (You et al., 2008mi; Watson et al., 2008). A clinical study in patients with coronary artery disease (CAD) concluded that hypertension was a major independent risk factor predictor of impaired EPCs-induced migration (Vasa et al., 2001). It was reported that the functional activity of EPCs is reduced in experimental model settings and in hypertensive patients, due to increased EPC-induced senescence (Imanishi et al., 2005). Recently, it was shown that in vivo endothelial repair capacity of early EPCs was reduced in patients with pre-hypertension and hypertension, due to EPC senescence and impaired endothelial function, which potentially represents an early event in the development of hypertension (Giannotti et al., 2010). Although it is still unclear, hypertension does not seem to have a direct action on EPCs reduction of half-life, which may be caused by telomerase inactivation associated with the increase in oxidative stress associated with hypertension (Higashi et al., 2002; Imanishi et al., 2005; Touyz et al., 2004). Further, studies showed that in patients with arterial hypertension, no association was observed between the number of circulating vascular progenitor cells and hypertension, suggesting that cell mobilization may not be affected (Delva et al., 2007; Werner et al., 2005). Inconsistently, it was also reported that reduced levels of circulating CD34+VEGFR-2+ EPCs were detected in hypertensive patients as compared to normotensive individuals (Pirro et al., 2007). Lower levels of peripheral EPCs correlated with a downregulation in the homeobox A9 (HOXA9) gene expression, which is critical for endothelial commitment during progenitor cell maturation (Pirro et al., 2007). Further studies are required to clarify the role of hypertension in EPCs functions. Nonetheless, it was also reported that anti-hypertensive drugs, besides its blood pressure lowering effect, may also improve vascular function through EPC activation (Cacciatore et al., 2011; de Ciuceis et al., 2011; Yao et al., 2007).

\subsection{Oxidative stress}

Increased oxidative stress has been proposed as an important molecular mechanism for vascular complications associated with DM, IR, and hypertension (Aronson, 2008; Houstis et al., 2006; Yanai et al., 2008), by exerting a direct cytotoxic effect on the vascular monolayer (Griendling \& FitzGerald, 2003). ROS may directly harm the vascular endothelium while superoxide reacts with $\mathrm{NO}$ to form peroxynitrite anion (ONOO-), a powerful oxidant (Griendling \& FitzGerald, 2003; Kuzkaya et al., 2003). Diminished release of eNO caused either by excessive oxidative degradation or impaired local production has been implicated in endothelial lining damage and insufficient repair capability due to deficient EPCs mobilization/functional status (Craeger et al., 2003; Yao et al., 2006). In fact, oxidative stressinduced reduction of $\mathrm{NO}$ bioavailability represents the major mechanism leading to 
impaired EPCs in vivo re-endothelialization capacity and in vitro function (Fleissner \& Thum, 2010; Sorrentino et al., 2007). NO deficient release by the vasculature is thought to impair EPCs migratory function and colony-forming ability, indicating a central role for eNO activity in EPC biology in increased oxidative stress conditions (Hill et al., 2003). Additonally, it was recently shown in patients with metabolic syndrome (MetS) and CAD, that oxidative stress may directly induce DNA damage on EPCs, by promoting telomere shortening with a consequent increase in their senescence rate, which contributed to the progression of atherosclerosis (Fleissner \& Thum, 2010; Satoh et al., 2008). Accordingly, antioxidant therapies, which exert cellular protective effects by directly scavenging ROS reducing their damaging action, can also improve EPCs functions and regenerative abilities (Marrotte et al., 2010).

\section{EPCs and diabetic retinopathy (DR)}

DR, the leading cause of visual impairment in the western world, will occur in the majority of T1DM patients and about $20-30 \%$ will advance to the blinding stage of the disease. It is expected that over $60 \%$ of patients with T2DM will develop retinopathy and with the global epidemic of obesity and subsequently of T2DM this predicament is likely to worsen (Fong et al., 2002). Retinal neovascularization in diabetes is stringently affected by alterations in the local microenviroenment. Hyperglycemia damages retinal microvasculature, which results in increased permeability, blood and serum leakage to the extravascular space, and progressive decline in retinal blood flow; as well as closure of the retinal microvasculature leading to DR. Retinal ischemia and release of angiogenic factors stimulate the proliferation of microvessels, leading to proliferative DR (PDR). Dysfunctional new vessel growth destroys the normal retinal architecture and capillary leakage causes diabetic macular edema (DME), the principal cause of vision loss in diabetes (Li Calzi et al., 2010). Up until recently, angiogenesis was thought to be the only process governing aberrant diabetic retinal neovascularization. However, retinal ischemia-induced release of specific factors may stimulate both local growth of vessels and the mobilization of BM-derived EPCs, which contribute to the development of PDR. Initial studies in PDR experimental models have shown that EPCs could be recruited to retinal sites of ischemic injury, playing a role in the revascularization of the retina (Goon et al., 2007; Grant et al., 2002). Although the mechanisms underlying EPCs roles are still under evaluation, it was reported that they may be mobilized and recruited to the diabetic retina in response to local secretion of VEGF and SDF-1. Moreover, studies in PDR experimental models and in diabetic patients presenting this complication have shown that SDF-1 seems to be the most important chemokine involved in the mobilization of EPCs to the retina (Butler et al., 2005; Csaky et al., 2004). In addition, the concentration of SDF-1 increases with the severity of DR, as evaluated in vitreous samples of T2DM individuals (Butler et al., 2005). Recently, it was also proposed that retinal neuronal tissue could play a role in promoting EPCs-mediated neovascularization (Liu et al., 2010). This study has demonstrated that higher levels of the neurotrophins Nerve Growth Factor (NGF) and Brain-Derived Neurotrophic Factor (BDNF) are present in the PB of DR patients, but not in non-diabetic controls or DM-PAD patients. Additionally, a strong correlation between these neurotrophins and EPC levels in DR patients was found, suggesting that retinal ischemia serves as a signal to stimulate BM-EPCs through selected strong neurotrophic factors that are released into the systemic circulation. Recently, two reports conveyed more important information on the role of different 
progenitor cells in various stages of DR in T1DM and T2DM patients (Brunner et al., 2009, 2011). In T1DM, it was demonstrated that in non-PDR patients there was a reduction in circulating EPCs, and that in PDR there was a dramatic increase of mature EPCs (Brunner et al., 2009). In addition, circulating EPCs of T1DM patients with PDR were reported to have increased clonogenic potential (Asnaghi et al., 2006). In T2DM patients with DR, circulating angiopoietic cells as EPCs, and mature EPCs had different regulations in PDR depending on each individual's macrovascular comorbidities (Brunner et al., 2011). Recent findings in diabetic patients have corroborated gathered experimental data, demonstrating that BMderived CD133+ EPCs, as well as, CD14+ monocytes could be mobilized to diabetic epiretinal membranes, contributing to vasculogenesis in PDR (Abu El-Asrar et al., 2011). Taken together, these data strengthen the importance of EPCs in the development of human PDR, highlighting the crucial role played by both the local retinal and the systemic environment.

\section{Modulating EPCs functions as therapeutic strategy}

It seems paradoxal that diabetic vascular complications, as PDR and PAD, may both affect the same patient, and alterations in EPCs exhibit opposing roles. This contradictory puzzle will most certainly have an influence when considering the modulating of EPCs levels/functions as therapeutic intervention. It has been shown that several vasculoprotective agents provided with beneficial cardiovascular effects, such as statins, thiazolidinediones (peroxisome proliferators-activated receptor-gamma; PPAR- $\gamma$ ), and anti-oxidants have been shown to improve endothelium-dependent vascular function and prevent atherosclerotic disease progression, by restoring EPCs properties and actions (Chen et al., 2011; Kusuyama et al., 2006; Schoonjans \& Auwerx, 2000). Additionally, and althougth there are no conclusive answers on the safety on EPCs therapies and of their potential undesidered side effects, pre-clinical and clinical studies have highlighted that autologous transplantation of several stem and progenitor cell populations ameliorated diabetic peripheral vascular complications (Procházka et al., 2009; Zhou et al., 2007). Nonetheless, the dysfunction of endogenous EPCs may limit the feasibility and efficiency of this approach, since their biological features are altered, which reduces their capacity to significantly improve therapeutic neovascularization. In addition, one might not neglect that there are several EPCs subtypes, which raises the question on what might be the best reparative BM-derived EPCs population (Figure 1). Further, would EPCs-based therapies provide any beneficial effects in retinal neovascularization? As aforementioned, retinal new vessel growth associated to diabetes is dysfunctional, destroying the normal retinal architecture. So we may assume that improving diabetic EPCs functions/transplanting non-diabetic EPCs to the retina may promote the re-endothelialization of acellular capillaries and the elimination of retinal ischemia. In fact, if intra-retinal neovascularization could be harnessed at the appropriate stage, ischemia could be contained or reversed (Figure 2). However, since the intravitreal delivery of antiangiogenic drugs may provide multiple benefits on DME and PDR (Arevalo et al., 2011; Chung et al., 2011), would the therapeutic use of EPCs be a better strategy for the treatment of DR? Many questions are still answered and in order to promote efficient EPCs-based therapies and to prevent harmful side effects, it is needed to go deeper into the molecular events accompanying alterations in diabetic vascular complications governing the diabetic-vasculogenic paradox. 
INCREASE

Biological functions

Re-endothelialization capacity

Neovascular formation
- Insulin sensitizing drugs -Anti-hypertensive medication - Anti-oxidants

-Vasculoprotective agents

- EPCs-based therapy (?)

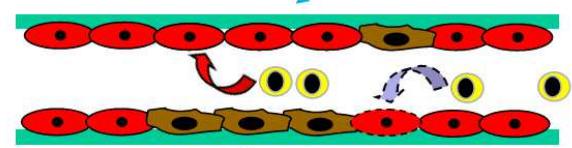

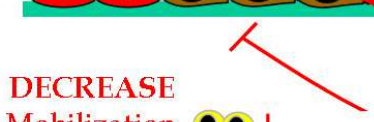

Mobilization

Viability

Differentiation

Clonogenic potential

Tubular formation capability

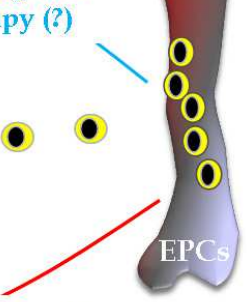

Vasculogenesis

-Hyperglicemia

- Insulin resistance

- Hypertension

- Oxidative stress

Fig. 1. Diabetes and peripheral vasculopathy. Diabetes related metabolic disorders decrease EPCs number and function being associated with impaired re-endothelialization and neovascular formation. Several agents may increase EPCs functions improving their revascularization capabilities. Adapted from Costa \& Vendeira, 2007.

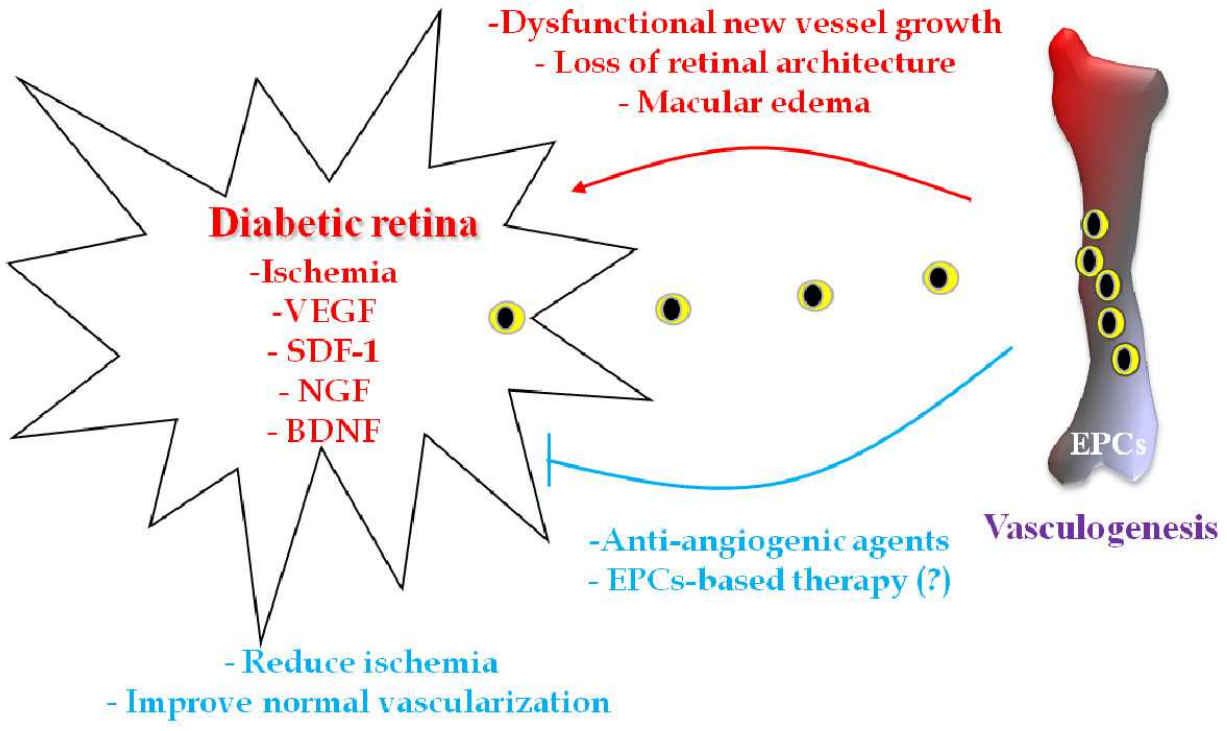

Fig. 2. Diabetic retinopathy. The ischemic retinal microenvironment and the production of vascular and neurothrophic factors promote increased EPCs recruitment and dysfunctional neovascular formation. Anti-angiogenic agents may improve retinal vascular architecture. 


\section{Concluding remarks}

Even though EPCs constitute a relatively small percentage of circulating cells, they can specifically and effectively home to sites of injury and partake in the regeneration and repair of endothelial beds. Besides the initially identified population of CD34+AC133+VEGFR-2+ EPCs, other subsets of EPCs and progenitor cells with vascular repair capability have been described. We have discussed the most recent data demonstrating that dysfunctions of several EPCs subpopulations may have a prominent role in the pathogenesis of diabetes systemic and retinal vascular complications. Both the decrease and increase of neovascular formation in diabetes seem differentially regulated by dysfunctional EPCs, which respond selectively to the local depletion/accumulation of growth factors, explaining the reasons why peripheral ischemia cannot stimulate EPCs recruitment, in opposition to what occurs in the retina. Further studies are required to identify the beneficial effects/safety of EPCsbased therapies. Additionally, it is mandatory to investigate the efficient use of EPCs in promoting neovascularization in peripheral vascular disease and the abrogation of retinal ischemia and altered vascular architecture. This carefull evaluation is crucial to further unveil the diabetic-vasculogenic paradox.

\section{References}

Abu El-Asrar AM, Struyf S, Verbeke H, Van Damme J, Geboes K (2011). Circulating bonemarrow-derived endothelial precursor cells contribute to neovascularization in diabetic epiretinal membranes. Acta Ophthalmol., 89(3), pp. (222-228), 1755-375X

Aicher A, Heeschen C, Mildner-Rihm C, Urbich C, Ihling C, Technau-Ihling K, Zeiher AM, Dimmeler S (2003). Essential role of endothelial nitric oxide synthase for mobilization of stem and progenitor cells. Nat Med., 9(11), pp. (1370-1376), 10788956

Aicher A, Zeiher AM, Dimmeler S (2005). Mobilizing endothelial progenitor cells. Hypertension, 45(3), pp. (321-325), 0194911X

Arevalo JF, Sanchez JG, Lasave AF, Wu L, Maia M, Bonafonte S, Brito M, Alezzandrini AA, Restrepo N, Berrocal MH, Saravia M, Farah ME, Fromow-Guerra J, Morales-Canton V (2011). Intravitreal Bevacizumab (Avastin) for Diabetic Retinopathy: The 2010 GLADAOF Lecture. J Ophthalmol., 2011, pp. (584238), 2090-0058

Aronson D (2008). Hyperglycemia and the pathobiology of diabetic complications. Adv Cardiol., 45, pp. (1-16), 0065-2326

Asahara T, Murohara T, Sullivan A, Silver M, van der Zee R, Li T, Witzenbichler B, Schatteman G, Isner JM (1997). Isolation of putative progenitor endothelial cells for angiogenesis. Science, 275(5302), pp. (964-967), 0036-8075

Asahara T, Takahashi T, Masuda H, Kalka C, Chen D, Iwaguro H, Inai Y, Silver M, Isner JM (1999a). VEGF contributes to postnatal neovascularization by mobilizing bone marrow-derived endothelial progenitor cells. EMBO J., 18(14), pp. (3964-3972), 0261-4189

Asahara T, Masuda H, Takahashi T, Kalka C, Pastore C, Silver M, Kearne M, Magner M, Isner JM (1999b). Bone marrow origin of endothelial progenitor cells responsible for postnatal vasculogenesis in physiological and pathological neovascularization. Circ Res., 85(3), pp. (221-228), 0009-7300 
Asnaghi V, Lattanzio R, Mazzolari G, Pastore MR, Ramoni A, Maestroni A, Ruggieri D, Luzi L, Brancato R, Zerbini G (2006). Increased clonogenic potential of circulating endothelial progenitor cells in patients with type 1 diabetes and proliferative retinopathy. Diabetologia, 49(5), pp. (1109-1111), 0012-186X

Balestrieri ML, Rienzo M, Felice F, Rossiello R, Grimaldi V, Milone L, Casamassimi A, Servillo L, Farzati B, Giovane A, Napoli C (2008a). High glucose downregulates endothelial progenitor cell number via SIRT1. Biochim Biophys Acta., 1784(6), pp. (936-945), 0006-3002

Blann AD, Pretorius A (2006). Circulating endothelial cells and endothelial progenitor cells: two sides of the same coin, or two different coins? Atherosclerosis, 188(1), pp. (1218), 0021-9150

Brunner S, Schernthaner GH, Satler M, Elhenicky M, Hoellerl F, Schmid-Kubista KE, Zeiler F, Binder S, Schernthaner G (2009). Correlation of different circulating endothelial progenitor cells to stages of diabetic retinopathy: first in vivo data. Invest Ophthalmol Vis Sci., 50(1), pp. (392-398), 0146-0404

Brunner S, Hoellerl F, Schmid-Kubista KE, Zeiler F, Schernthaner G, Binder S, Schernthaner GH. Circulating angiopoietic cells and diabetic retinopathy in T2DM patients with and without macrovascular disease. Invest Ophthalmol Vis Sci. 2011 Mar 11. [Epub ahead of print], 0146-0404

Butler JM, Guthrie SM, Koc M, Afzal A, Caballero S, Brooks HL, Mames RN, Segal MS, Grant MB, Scott EW (2005). SDF-1 is both necessary and sufficient to promote proliferative retinopathy. J Clin Invest., 115(1), pp. (86-93), 0021-9738

Cacciatore F, Bruzzese G, Vitale DF, Liguori A, de Nigris F, Fiorito C, Infante T, Donatelli F, Minucci PB, Ignarro LJ, Napoli C. Effects of ACE inhibition on circulating endothelial progenitor cells, vascular damage, and oxidative stress in hypertensive patients. Eur J Clin Pharmacol. 2011, [Epub ahead of print], 0031-6970

Callaghan MJ, Ceradini DJ, Gurtner GC (2005). Hyperglycemia-induced reactive oxygen species and impaired endothelial progenitor cell function. Antioxid Redox Signal., 7(11-12), pp. (1476-1482), 1523-0864

Case J, Mead LE, Bessler WK, Prater D, White HA, Saadatzadeh MR, Bhavsar JR, Yoder MC, Haneline LS, Ingram DA (2007). Human CD34+AC133+VEGFR-2+ cells are not endothelial progenitor cells but distinct, primitive hematopoietic progenitors. Exp Hematol., 35(7), pp. (1109-1118), 0301-472X

Chen YH, Lin SJ, Lin FY, Wu TC, Tsao CR, Huang PH, Liu PL, Chen YL, Chen JW (2007). High glucose impairs early and late endothelial progenitor cells by modifying nitric oxide-related but not oxidative stress-mediated mechanisms. Diabetes, 56(6), pp. (1559-1568), 0012-1797

Chen J, Song M, Yu S, Gao P, Yu Y, Wang H, Huang L (2010). Advanced glycation endproducts alter functions and promote apoptosis in endothelial progenitor cells through receptor for advanced glycation endproducts mediate overpression of cell oxidant stress. Mol Cell Biochem., 335(1-2), pp. (137-146), 0300-8177

Chen LL, Yu F, Zeng TS, Liao YF, Li YM, Ding HC (2011). Effects of gliclazide on endothelial function in patients with newly diagnosed type 2 diabetes. Eur J Pharmacol., 659(23), pp. (296-301), 0014-2999 
Chung EJ, Kang SJ, Koo JS, Choi YJ, Grossniklaus HE, Koh HJ (2011). Effect of intravitreal bevacizumab on vascular endothelial growth factor expression in patients with proliferative diabetic retinopathy. Yonsei Med J., 52(1), pp. (151-157), 0513-5796

Churdchomjan W, Kheolamai P, Manochantr S, Tapanadechopone P, Tantrawatpan C, UPratya Y, Issaragrisil S (2010). Comparison of endothelial progenitor cell function in type 2 diabetes with good and poor glycemic control.BMC Endocr Disord., 10:5, (1472-6823), 1472-6823

Ciulla TA, Amador AG, Zinman B (2003). Diabetic retinopathy and diabetic macular edema: pathophysiology, screening, and novel therapies. Diabetes Care, 26(9), pp. (26532664), 0149-5992

Costa C, Incio J, Soares, R (2007). Angiogenesis and chronic inflammation: cause or consequence? Angiogenesis, 10(3), pp. (149-166), 0969-6970

Costa C, Vendeira P. (2007). Penis and endothelium - Extra genital aspects of erectile dysfunction. Rev Int Androl., 5(1), pp. (50-58), 1698-031X

Creager MA, Luscher TF, Cosentino F, Beckman JA (2003). Diabetes and vascular disease: pathophysiology, clinical consequences, and medical therapy, part I. Circulation, 108(12), pp. (1527-1532), 0009-7322

Csaky KG, Baffi JZ, Byrnes GA, Wolfe JD, Hilmer SC, Flippin J, Cousins SW (2004). Recruitment of marrow-derived endothelial cells to experimental choroidal neovascularization by local expression of vascular endothelial growth factor. Exp. Eye Res., 78(6), pp. (1107-1116), 0014-4835

Cubbon RM, Rajwani A, Wheatcroft SB (2007). The impact of insulin resistance on endothelial function, progenitor cells and repair. Diab Vasc Dis Res., 4(2), pp. (103111), 1479-1641

Cubbon RM, Kahn MB, Wheatcroft SB (2009). Effects of insulin resistance on endothelial progenitor cells and vascular repair. Clin Sci (Lond)., 117(5), pp. (173-190), 0143-5221

Dandona P, Aljada A, Chaudhuri A, Bandyopadhyay A (2003). The potential influence of inflammation and insulin resistance on the pathogenesis and treatment of atherosclerosis-related complications in type 2 diabetes. J Clin Endocrinol Metab., 88(6), pp. (2422-2429), 0021-972X

Dandona P, Aljada A, Bandyopadhyay A (2004). Inflammation: the link between insulin resistance, obesity and diabetes. Trends Immunol., 25(1), pp. (4-7), 1471-4906

de Ciuceis C, Pilu A, Rizzoni D, Porteri E, Muiesan ML, Salvetti M, Paini A, Belotti E, Zani F, Boari GE, Rosei CA, Rosei EA (2011). Effect of antihypertensive treatment on circulating endothelial progenitor cells in patients with mild essential hypertension. Blood Press., 20(2), pp. (77-83), 0803-7051

De Palma M, Venneri MA, Galli R, Sergi Sergi L, Politi LS, Sampaolesi M, Naldini L (2005). Tie2 identifies a hematopoietic lineage of proangiogenic monocytes required for tumor vessel formation and a mesenchymal population of pericyte progenitors. Cancer Cell, 2005; 8(3), pp. (211-226), 1535-6108

Delva P, Degan M, Vallerio P, Arosio E, Minuz P, Amen G, Di Chio M, Lechi A (2007). Endothelial progenitor cells in patients with essential hypertension. J Hypertens., 25(1) , pp. (127-132), 0263-6352

Desouza CV, Hamel FG, Bidasee K, O'Connell K (2011). Role of inflammation and insulin resistance in endothelial progenitor cell dysfunction. Diabetes., 60(4), pp. (12861294), 0012-1797 
Duh E, Aiello LP (1999). Vascular endothelial growth factor and diabetes: the agonist versus antagonist paradox. Diabetes, 48(10), pp. (1899-1906), 0012-1797

Egan CG, Lavery R, Caporali F, Fondelli C, Laghi-Pasini F, Dotta F, Sorrentino V (2008). Generalised reduction of putative endothelial progenitors and CXCR4-positive peripheral blood cells in type 2 diabetes. Diabetologia, 51(7), pp. (1296-1305), 0012186X

Fadini GP, Miorin M, Facco M, Bonamico S, Baesso I, Grego F, Menegolo M, de Kreutzenberg SV, Tiengo A, Agostini C, Avogaro A (2005). Circulating endothelial progenitor cells are reduced in peripheral vascular complications of type 2 diabetes mellitus. J Am Coll Cardiol., 45(9), pp. (1449-1457), 0735-1097

Fadini GP, Sartore S, Albiero M, Baesso I, Murphy E, Menegolo M, Grego F, Vigili de Kreutzenberg S, Tiengo A, Agostini C, Avogaro A (2006a). Number and function of endothelial progenitor cells as a marker of severity for diabetic vasculopathy. Arterioscler Thromb Vasc Biol., 26(9), pp. (2140-2146), 1079-5642

Fadini GP, Sartore S, Schiavon M, Albiero M, Baesso I, Cabrelle A, Agostini C, Avogaro A (2006b). Diabetes impairs progenitor cell mobilisation after hindlimb ischaemiareperfusion injury in rats. Diabetologia, 49(12), pp. (3075-3084), 0012-186X

Fadini GP, Sartore S, Baesso I, Lenzi M, Agostini C, Tiengo A, Avogaro A (2006c). Endothelial progenitor cells and the diabetic paradox. Diabetes Care, 29(3), pp. (714716), 0149-5992

Fang S, Salven P (2011). Stem cells in tumor angiogenesis. J Mol Cell Cardiol., 50(2), pp. (290295), 0022-2828

Fleissner F, Thum T. Critical Role of the Nitric Oxide/Reactive Oxygen Species Balance in Endothelial Progenitor Dysfunction. Antioxid Redox Signal. 2010 Dec 13. [Epub ahead of print], 1523-0864

Folkman J (1984). What is the role of endothelial cells in angiogenesis? Lab Invest., 51(6), pp. 601-604, 0023-6837

Fong DS, Sharza M, Chen W, Paschal JF, Ariyasu RG, Lee PP (2002). Vision loss among diabetics in a group model Health Maintenance Organization (HMO). Am J Ophthalmol., 133(2), pp. (236-241), 0002-9394

Foresta C, Schipilliti M, De Toni L, Magagna S, Lancerotto L, Azzena B, Vindigni V, Mazzoleni F (2011). Blood levels, apoptosis, and homing of the endothelial progenitor cells after skin burns and escharectomy. J Trauma, 70(2), pp. (459-465), 0022-5282

Freundlich B, Avdalovic N (1983). Use of gelatin/plasma coated flasks for isolating human peripheral blood monocytes. J Immunol Methods, 62(1), pp. (31-37), 0022-1759

Friedrich EB, Walenta K, Scharlau J, Nickenig G, Werner N (2006). CD34-/CD133+/VEGFR$2+$ endothelial progenitor cell subpopulation with potent vasoregenerative capacities. Circ Res., 98(3), pp. (e20-25), 0009-7330

Gallagher KA, Liu ZJ, Xiao M, Chen H, Goldstein LJ, Buerk DG, Nedeau A, Thom SR, Velazquez OC (2007). Diabetic impairments in NO-mediated endothelial progenitor cell mobilization and homing are reversed by hyperoxia and SDF-1 alpha. J Clin Invest., 117(5), pp. (1249-1259), 0021-9738

Gensch C, Clever YP, Werner C, Hanhoun M, Böhm M, Laufs U (2007). The PPAR-gamma agonist pioglitazone increases neoangiogenesis and prevents apoptosis of endothelial progenitor cells. Atherosclerosis., 192(1), pp. (67-74), 0021-9150 
Giannotti G, Doerries C, Mocharla PS, Mueller MF, Bahlmann FH, Horvàth T, Jiang H, Sorrentino SA, Steenken N, Manes C, Marzilli M, Rudolph KL, Lüscher TF, Drexler $\mathrm{H}$, Landmesser U (2010). Impaired endothelial repair capacity of early endothelial progenitor cells in prehypertension: relation to endothelial dysfunction. Hypertension, 55(6), pp. (1389-1397), 0194911X

Gill M, Dias S, Hattori K, Rivera ML, Hicklin D, Witte L, Girardi L, Yurt R, Himel H, Rafii S (2001). Vascular trauma induces rapid but transient mobilization of VEGFR2(+)AC133(+) endothelial precursor cells. Circ Res., 88(2), pp. (167-174), 0009-7330

Goon PK, Lip GY (2007). Involvement of circulating endothelial progenitor cells and vasculogenic factors in the pathogenesis of diabetic retinopathy. Eye, 21(6), pp. (838-839), 0950-222X

Grant MB, May WS, Caballero S, Brown GA, Guthrie SM, Mames RN, Byrne BJ, Vaught T, Spoerri PE, Peck AB, Scott EW (2002). Adult hematopoietic stem cells provide functional hemangioblast activity during retinal neovascularization. Nat. Med., 8(6), pp. (607-612), 1078-8956

Griendling KK, FitzGerald GA (2003). Oxidative stress and cardiovascular injury. Part II. Animal and human studies. Circulation, 108(17), pp. (2034-2040), 0009-7322

Grunewald M, Avraham I, Dor Y, Bachar-Lustig E, Itin A, Jung S, Chimenti S, Landsman L, Abramovitch R, Keshet E (2006). VEGF-induced adult neovascularization: recruitment, retention, and role of accessory cells. Cell, 124(1), pp. (175-189), 00928674

Gulati R, Jevremovic D, Peterson TE, Chatterjee S, Shah V, Vile RG, Simari RD (2003). Diverse origin and function of cells with endothelial phenotype obtained from adult human blood. Circ Res., 93(11), pp. (1023-1025), 0009-7300

Haffner SM, Lehto S, Rönnemaa T, Pyörälä K, Laakso M (1998). Mortality from coronary heart disease in subjects with type 2 diabetes and in nondiabetic subjects with and without prior myocardial infarction. N Engl J Med., 339(4), pp. (229-234), 0028-4793

Heissig B, Hattori K, Dias S, Friedrich M, Ferris B, Hackett NR, Crystal RG, Besmer P, Lyden D, Moore MA, Werb Z, Rafii S (2002). Recruitment of stem and progenitor cells from the bone marrow niche requires MMP-9 mediated release of kit-ligand. Cell, 109(5), pp. (625-37), 0092-8674

Higashi Y, Sasaki S, Nakagawa K, Matsuura H, Oshima T, Chayama K (2002). Endothelial function and oxidative stress in renovascular hypertension. N Engl J Med., 346(25), pp. (1954-1962), 0028-4793

Hill JM, Zalos G, Halcox JP, Schenke WH, Waclawiw MA, Quyyumi AA, Finkel T (2003). Circulating endothelial progenitor cells, vascular function, and cardiovascular risk. N Engl J Med., 348(7), pp. (593-600), 0028-4793

Hirschi KK, Ingram DA, Yoder MC (2008). Assessing identity, phenotype, and fate of endothelial progenitor cells. Arterioscler Thromb Vasc Biol., 28(9), pp. (1584-1595), 1079-5642

Houstis N, Rosen ED, Lander ES (2006). Reactive oxygen species have a causal role in multiple forms of insulin resistance. Nature., 440(7086), pp. (944-948), 0028-0836

Hristov M, Erl W, Weber PC (2003). Endothelial progenitor cells: isolation and characterization. Trends Cardiovasc Med., 13(5), pp. (201-206), 1050-1738 
Hur J, Yoon CH, Kim HS, Choi JH, Kang HJ, Hwang KK, Oh BH, Lee MM, Park YB (2004). Characterization of two types of endothelial progenitor cells and their different contributions to neovasculogenesis. Arterioscler Thromb Vasc Biol., 24(2), pp. (288293), 1079-5642

Imanishi T, Moriwaki C, Hano T, Nishio I (2005). Endothelial progenitor cell senescence is accelerated in both experimental hypertensive rats and patients with essential hypertension. J Hypertens., 23(10), pp. (1831-1837), 0263-6352

Ingram DA, Mead LE, Moore DB, Woodard W, Fenoglio A, Yoder MC (2005). Vessel wallderived endothelial cells rapidly proliferate because they contain a complete hierarchy of endothelial progenitor cells. Blood, 105(7), pp. (2783-2786), 0006-4971

Ingram DA, Lien IZ, Mead LE, Estes M, Prater DN, Derr-Yellin E, DiMeglio LA, Haneline LS (2008). In vitro hyperglycemia or a diabetic intrauterine environment reduces neonatal endothelial colony-forming cell numbers and function. Diabetes, 57(3), pp. (724-731), 0012-1797

Jandeleit-Dahm K, Cooper ME (2008). The role of AGEs in cardiovascular disease. Curr Pharm Des., 14(10), pp. (979-986), 1381-6128

Jung C, Rafnsson A, Shemyakin A, Böhm F, Pernow J (2010). Different subpopulations of endothelial progenitor cells and circulating apoptotic progenitor cells in patients with vascular disease and diabetes. Int J Cardiol., 143(3), pp. (368-372), 0167-5273

Kahn MB, Yuldasheva NY, Cubbon RM, Smith J, Rashid ST, Viswambharan H, Imrie H, Abbas A, Rajwani A, Aziz A, Baliga V, Sukumar P, Gage M, Kearney MT, Wheatcroft SB (2011). Insulin resistance impairs circulating angiogenic progenitor cell function and delays endothelial regeneration. Diabetes, 60(4), pp. (1295-1303), 0012-1797

Kang L, Chen Q, Wang L, Gao L, Meng K, Chen J, Ferro A, Xu B. (2009). Decreased Mobilization of Endothelial Progenitor Cells Contributes to Impaired neovascularization in Diabetes. Clin Exp Pharmacol Physiol., 36(10), pp. (e47-56), 0143-9294

Kaplan RN, Riba RD, Zacharoulis S, Bramley AH, Vincent L, Costa C, MacDonald DD, Jin DK, Shido K, Kerns SA, Zhu Z, Hicklin D, Wu Y, Port JL, Altorki N, Port ER, Ruggero D, Shmelkov SV, Jensen KK, Rafii S, Lyden D (2005). VEGFR1-positive haematopoietic bone marrow progenitors initiate the pre-metastatic niche. Nature, 438(7069), pp. (820-827), 0028-0836

Kim JA, Montagnani M, Koh KK, Quon MJ (2006). Reciprocal relationships between insulin resistance and endothelial dysfunction: molecular and pathophysiological mechanisms. Circulation, 113(15), pp. (1888-1904), 0009-7322

Kirton JP, Xu Q (2010). Endothelial precursors in vascular repair. Microvasc Res., 79(3), pp. (193-199), 0026-2862

Kränkel N, Adams V, Linke A, Gielen S, Erbs S, Lenk K, Schuler G, Hambrecht R (2005). Hyperglycemia reduces survival and impairs function of circulating blood-derived progenitor cells. Arterioscler Thromb Vasc Biol., 25(4), pp. (698-703), 1079-5642

Kuki S, Imanishi T, Kobayashi K, Matsuo Y, Obana M, Akasaka T (2006). Hyperglycemia accelerated endothelial progenitor cell senescence via the activation of p38 mitogen-activated protein kinase. Circ J., 70(8), pp. (1076-1081), 1346-9843 
Kusuyama T, Omura T, Nishiya D, Enomoto S, Matsumoto R, Murata T, Takeuchi K, YoshikawaJ, Yoshiyama M (2006). The effects of HMG-CoA reductase inhibitor on vascular progenitor cells. J. Pharmacol. Sci., 101(4), pp. (344-349), 1347-8613

Kuzkaya N, Weissmann N, Harrison DG, Dikalov S (2003). Interactions of peroxynitrite, tetrahydrobiopterin, ascorbic acid, and thiols: implications for uncoupling endothelial nitric-oxide synthase. J Biol Chem., 278(25), pp. (22546-2254), 0021-9258

Li Calzi S, Neu MB, Shaw LC, Grant MB (2010). Endothelial progenitor dysfunction in the pathogenesis of diabetic retinopathy: treatment concept to correct diabetesassociated deficits. EPMA J., 1(1), pp. (88-100), 1878-5077

Liang C, Ren Y, Tan H, He Z, Jiang Q, Wu J, Zhen Y, Fan M, Wu Z (2009). Rosiglitazone via upregulation of Akt/eNOS pathways attenuates dysfunction of endothelial progenitor cells, induced by advanced glycation end products. $\mathrm{Br}$ J Pharmacol., 158(8), pp. (1865-1873), 0007-1188

Liu X, Li Y, Liu Y, Luo Y, Wang D, Annex BH, Goldschmidt-Clermont PJ (2010). Endothelial progenitor cells (EPCs) mobilized and activated by neurotrophic factors may contribute to pathologic neovascularization in diabetic retinopathy. Am J Pathol., 176(1), pp. (504-515), 0002-9440

Loomans CJ, van Haperen R, Duijs JM, Verseyden C, de Crom R, Leenen PJ, Drexhage HA, de Boer HC, de Koning EJ, Rabelink TJ, Staal FJ, van Zonneveld AJ (2009). Differentiation of bone marrow-derived endothelial progenitor cells is shifted into a proinflammatory phenotype by hyperglycemia. Mol Med., 15(5-6), pp. (152-159), 1528-3658

Lyden D, Hattori K, Dias S, Costa C, Blaikie P, Butros L, Chadburn A, Heissig B, Marks W, Witte L, Wu Y, Hicklin D, Zhu Z, Hackett NR, Crystal RG, Moore MA, Hajjar KA, Manova K, Benezra R, Rafii S (2001). Impaired recruitment of bone-marrowderived endothelial and hematopoietic precursor cells blocks tumor angiogenesis and growth. Nat. Med., 7(11), pp. (1194-1201), 1078-8956

Madonna R, De Caterina R. Cellular and molecular mechanisms of vascular injury in diabetes - Part II: Cellular mechanisms and therapeutic targets. Vascul Pharmacol. 2011 Mar 29. [Epub ahead of print], 1537-1891

Marfella R, Esposito K, Nappo F, Siniscalchi M, Sasso FC, Portoghese M, Di Marino MP, Baldi A, Cuzzocrea S, Di Filippo C, Barboso G, Baldi F, Rossi F, D’Amico M, Giugliano D (2004). Expression of angiogenic factors during acute coronary syndromes in human type 2 diabetes. Diabetes, 53(9), pp. (2383-2391), 0012-1797

Marrotte EJ, Chen DD, Hakim JS, Chen AF (2010). Manganese superoxide dismutase expression in endothelial progenitor cells accelerates wound healing in diabetic mice. J Clin Invest., 120(12), pp. (4207-4219), 0021-9738

Matsumoto T, Mifune Y, Kawamoto A, Kuroda R, Shoji T, Iwasaki H, Suzuki T, Oyamada A, Horii M, Yokoyama A, Nishimura H, Lee SY, Miwa M, Doita M, Kurosaka M, Asahara $\mathrm{T}$ (2008). Fracture induced mobilization and incorporation of bone marrow-derived endothelial progenitor cells for bone healing. J Cell Physiol., 215(1), pp. (234-242), 0021-9541

Medina RJ, O'Neill CL, Sweeney M, Guduric-Fuchs J, Gardiner TA, Simpson DA, Stitt AW (2010). Molecular analysis of endothelial progenitor cell (EPC) subtypes reveals two distinct cell populations with different identities. BMC Med Genomics, 3, pp. (18), 1755-8794 
Nakagami H, Kaneda Y, Ogihara T, Morishita R (2005). Endothelial dysfunction in hyperglycemia as a trigger of atherosclerosis. Curr Diabetes Rev., 1(1), pp. (59-63), 1573-3998

Peichev M, Naiyer AJ, Pereira D, Zhu Z, Lane WJ, Williams M, Oz MC, Hicklin DJ, Witte L, Moore MA, Rafii S (2000). Expression of VEGFR-2 and AC133 by circulating human CD34(+) cells identifies a population of functional endothelial precursors. Blood, 95(3), pp. (952-958), 0006-4971

Perkins I (2004). Diabetes mellitus epidemiology-classification, determinants, and public health impacts. J Miss State Med Assoc., 45(12), pp. (355-362), 0026-6396

Perticone F, Ceravolo R, Pujia A, Ventura G, Iacopino S, Scozzafava A, Ferraro A, Chello M, Mastroroberto P, Verdecchia P, Schillaci G (2001). Prognostic significance of endothelial dysfunction in hypertensive patients. Circulation, 104(2), pp. (191-196), 0009-7322

Peters BA, Diaz LA, Polyak K, Meszler L, Romans K, Guinan EC, Antin JH, Myerson D, Hamilton SR, Vogelstein B, Kinzler KW, Lengauer C (2005). Contribution of bone marrow-derived endothelial cells to human tumor vasculature. Nat Med., 11(3), pp. (261-262), 1078-8956

Pirro M, Schillaci G, Menecali C, Bagaglia F, Paltriccia R, Vaudo G, Mannarino MR, Mannarino E (2007). Reduced number of circulating endothelial progenitors and HOXA9 expression in CD34+ cells of hypertensive patients. J Hypertens., 25(10), pp. (2093-2099), 0263-6352

Porto I, Leone AM, De Maria GL, Craig CH, Tritarelli A, Camaioni C, Natale L, Niccoli G, Biasucci LM, Crea F. Are endothelial progenitor cells mobilized by myocardial ischemia or myocardial necrosis? A cardiac magnetic resonance study. Atherosclerosis. 2011 Feb 17. [Epub ahead of print], 0021-9150

Povsic TJ, Goldschmidt-Clermont PJ (2008). Endothelial progenitor cells: markers of vascular reparative capacity. Ther Adv Cardiovasc Dis., 2(3), pp. (199-113), 1753-9447

Procházka V, Gumulec J, Chmelová J, Klement P, Klement GL, Jonszta T, Czerný D, Krajca J (2009). Autologous bone marrow stem cell transplantation in patients with endstage chronical critical limb ischemia and diabetic foot. Vnitr. Lek., 55(3), pp. (173178), 0042-773X

Prokopi M, Pula G, Mayr U, Devue C, Gallagher J, Xiao Q, Boulanger CM, Westwood N, Urbich C, Willeit J, Steiner M, Breuss J, Xu Q, Kiechl S, Mayr M (2009). Proteomic analysis reveals presence of platelet microparticles in endothelial progenitor cell cultures. Blood, 114(3), pp. (723-732), 0006-4971

Purhonen S, Palm J, Rossi D, Kaskenpää N, Rajantie I, Ylä-Herttuala S, Alitalo K, Weissman IL, Salven P (2008). Bone marrow-derived circulating endothelial precursors do not contribute to vascular endothelium and are not needed for tumor growth. Proc Natl Acad Sci U S A., 105(18), pp. (6620-6625), 0027-8424

Rehman J, Li J, Orschell CM, March KL (2003). Peripheral blood “endothelial progenitor cells" are derived from monocyte/macrophages and secrete angiogenic growth factors. Circulation, 107(8), pp. (1164-1169), 0009-7322

Risau W, Flamme I (1995). Vasculogenesis. Annu Rev Cell Dev Biol., 11, pp. (73-91), 1081-0706

Risau, W. Mechanisms of angiogenesis (1997). Nature, 386(6626), pp. (671-674), 0028-0836

Satoh M, Ishikawa Y, Takahashi Y, Itoh T, Minami Y, Nakamura M (2008). Association between oxidative DNA damage and telomere shortening in circulating endothelial 
progenitor cells obtained from metabolic syndrome patients with coronary artery disease. Atherosclerosis, 198(2), pp. (347-353), 0021-9150

Schiffrin EL (2001). A critical review of the role of endothelial factors in the pathogenesis of hypertension. J Cardiovasc Pharmacol., 38(Suppl 2), pp. (S3-S6), 0160-2446

Schoonjans K, Auwerx J (2000). Thiazolidinediones: an update. Lancet, 355(9208), pp. (10081110), 0140-6736

Shantsila E, Watson T, Lip GY (2007). Endothelial progenitor cells in cardiovascular disorders. J Am Coll Cardiol., 49(7), pp. (741-752), 0735-1097

Shen C, Li Q, Zhang YC, Ma G, Feng Y, Zhu Q, Dai Q, Chen Z, Yao Y, Chen L, Jiang Y, Liu N (2010). Advanced glycation endproducts increase EPC apoptosis and decrease nitric oxide release via MAPK pathways. Biomed Pharmacother., 64(1), pp. (35-43), 0753-3322

Shi Q, Rafii S, Wu MH, Wijelath ES, Yu C, Ishida A, Fujita Y, Kothari S, Mohle R, Sauvage LR, Moore MA, Storb RF, Hammond WP (1998). Evidence for circulating bone marrow-derived endothelial cells. Blood, 92(2), pp. (362-367), 0006-4971

Shintani S, Murohara T, Ikeda H, Ueno T, Honma T, Katoh A, Sasaki K, Shimada T, Oike Y, Imaizumi T (2001). Mobilization of endothelial progenitor cells in patients with acute myocardial infarction. Circulation, 103(23), pp. (2776-2779), 0009-7322

Sorrentino SA, Bahlmann FH, Besler C, Müller M, Schulz S, Kirchhoff N, Doerries C, Horváth T, Limbourg A, Limbourg F, Fliser D, Haller H, Drexler H, Landmesser U (2007). Oxidant stress impairs in vivo reendothelialization capacity of endothelial progenitor cells from patients with type 2 diabetes mellitus: restoration by the peroxisome proliferator-activated receptor-gamma agonist rosiglitazone. Circulation, 116(2), pp. (163-173), 0009-7322

Spieker LE, Noll G, Ruschitzka FT, Maier W, Luscher TF (2000). Working under pressure: the vascular endothelium in arterial hypertension. J Hum Hypertens., 14(10-11), pp. (617-630), 0950-9240

Takahashi T, Kalka C, Masuda H, Chen D, Silver M, Kearney M, Magner M, Isner JM, Asahara T (1999). Ischemia- and cytokine-induced mobilization of bone marrowderived endothelial progenitor cells for neovascularization. Nat. Med., 5(4), pp. (434-438), 1078-8956

Takakura N (2006). Role of hematopoietic lineage cells as accessory components in blood vessel formation. Cancer Sci., 97(7), pp. (568-574), 1347-9032

Tepper OM, Galiano RD, Capla JM, Kalka C, Gagne PJ, Jacobowitz GR, Levine JP, Gurtner GC (2002). Human endothelial progenitor cells from type II diabetics exhibit impaired proliferation, adhesion, and incorporation into vascular structures. Circulation, 106(22), pp. (2781-2786), 0009-7322

Timmermans F, Van Hauwermeiren F, De Smedt M, Raedt R, Plasschaert F, De Buyzere ML, Gillebert TC, Plum J, Vandekerckhove B (2007). Endothelial outgrowth cells are not derived from CD133+ cells or CD45+ hematopoietic precursors. Arterioscler Thromb Vasc Biol., 27(7), pp. (1572-1579), 1079-5642

Timmermans F, Plum J, Yöder MC, Ingram DA, Vandekerckhove B, Case J (2009). Endothelial progenitor cells: identity defined? J Cell Mol Med., 13(1), pp. (87-102), 1582-1838

Touyz RM, Schiffrin EL (2004). Reactive oxygen species in vascular biology: implications in hypertension. Histochem Cell Biol., 122(4), pp. (339-352), 0948-6143 
Urbich C, Aicher A, Heeschen C, Dernbach E, Hofmann WK, Zeiher AM, Dimmeler S. (2005). Soluble factors released by endothelial progenitor cells promote migration of endothelial cells and cardiac resident progenitor cells. J Mol Cell Cardiol., 39(5), pp. (733-742), 0022-2828

Vasa M, Fichtlscherer S, Aicher A, Adler K, Urbich C, Martin H, Zeiher AM, Dimmeler S (2001). Number and migratory activity of circulating endothelial progenitor cells inversely correlate with risk factors for coronary artery disease. Circ Res., 89(1), pp. (E1-7), 0009-7300

Vöö S, Dunaeva M, Eggermann J, Stadler N, Waltenberger J (2009). Diabetes mellitus impairs CD133+ progenitor cell function after myocardial infarction. J Intern Med., 265(2), pp. (238-249), 0954-6820

Watson T, Goon PK, Lip GY (2008). Endothelial progenitor cells, endothelial dysfunction, inflammation, and oxidative stress in hypertension. Antioxid Redox Signal., 10(6), pp. (1079-1088), 1523-0864

Werner N, Kosiol S, Schiegl T, Ahlers P, Walenta K, Link A, Böhm M, Nickenig G (2005). Circulating endothelial progenitor cells and cardiovascular outcomes. $N$ Engl J Med., 353(10), pp. (999-1007), 0028-4793

Yanai H, Tomono Y, Ito K, Furutani N, Yoshida H, Tada N (2008). The underlying mechanisms for development of hypertension in the metabolic syndrome. Nutr J., 7 , pp. (10-15), 1475-2891

Yao EH, Yu Y, Fukuda N (2006). Oxidative stress on progenitor and stem cells in cardiovascular diseases. Curr Pharm Biotechnol., 7(2), pp. (101-108), 1389-2010

Yao EH, Fukuda N, Matsumoto T, Kobayashi N, Katakawa M, Yamamoto C, Tsunemi A, Suzuki R, Ueno T, Matsumoto K (2007). Losartan improves the impaired function of endothelial progenitor cells in hypertension via an antioxidant effect. Hypertens Res., 30(11), pp. (1119-1128), 0916-9636

Yoder MC, Mead LE, Prater D, Krier TR, Mroueh KN, Li F, Krasich R, Temm CJ, Prchal JT, Ingram DA (2007). Redefining endothelial progenitor cells via clonal analysis and hematopoietic stem/progenitor cell principals. Blood, 109(5), pp. 1801-1819, 00064971

Yoder MC (2009). Defining human endothelial progenitor cells. J Thromb Haemost., 7(Suppl 1), pp. (49-52), 1538-7933

Yoon CH, Hur J, Park KW, Kim JH, Lee CS, Oh IY, Kim TY, Cho HJ, Kang HJ, Chae IH, Yang HK, Oh BH, Park YB, Kim HS (2005a). Synergistic neovascularization by mixed transplantation of early endothelial progenitor cells and late outgrowth endothelial cells: the role of angiogenic cytokines and matrix metalloproteinases. Circulation, 112(11), pp. (1618-1627), 0009-7322

Yoon YS, Uchida S, Masuo O, Cejna M, Park JS, Gwon HC, Kirchmair R, Bahlman F, Walter D, Curry C, Hanley A, Isner JM, Losordo DW (2005b). Progressive attenuation of myocardial vascular endothelial growth factor expression is a seminal event in diabetic cardiomyopathy: restoration of microvascular homeostasis and recovery of cardiac function in diabetic cardiomyopathy after replenishment of local vascular endothelial growth factor. Circulation, 111(16), pp. (2073-2085), 0009-7322

You D, Cochain C, Loinard C, Vilar J, Mees B, Duriez M, Lévy BI, Silvestre JS (2008). Hypertension impairs postnatal vasculogenesis: role of antihypertensive agents. Hypertension, 51(6), pp. (1537-1544), 0194-911X 
Zhang SJ, Zhang H, Wei YJ, Su WJ, Liao ZK, Hou M, Zhou JY, Hu SS (2006). Adult endothelial progenitor cells from human peripheral blood maintain monocyte/macrophage function throughout in vitro culture. Cell Res., 16(6), pp. (577-584), 1001-0602

Zhang SJ, Zhang H, Hou M, Zheng Z, Zhou J, Su W, Wei Y, Hu S (2007). Is it possible to obtain "true endothelial progenitor cells" by in vitro culture of bone marrow mononuclear cells? Stem Cells Dev., 16(4), pp. (683-690), 1547-3287

Zhou B, Cao XC, Fang ZH, Zheng CL, Han ZB, Ren H, Poon MC, Han ZC (2007). Prevention of diabetic microangiopathy by prophylactic transplant of mobilized peripheral blood mononuclear cells. Acta. Pharmacol. Sin., (1), pp. (89-97), 1671-4083

Zimmet P, Alberti KG, Shaw J (2001). Global and societal implications of the diabetes epidemic. Nature, 414(6865), pp. (782-787), 0028-0836 


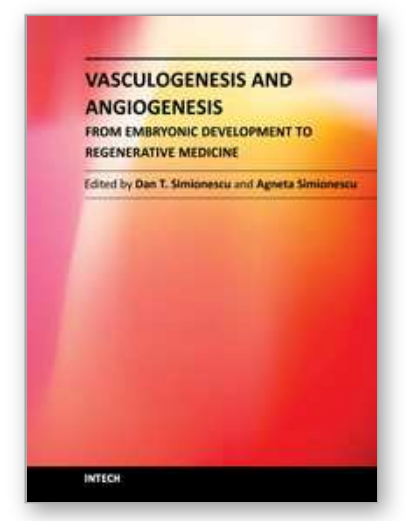

\author{
Vasculogenesis and Angiogenesis - from Embryonic Development \\ to Regenerative Medicine \\ Edited by Dr. Dan Simionescu
}

ISBN 978-953-307-882-3

Hard cover, 226 pages

Publisher InTech

Published online 07, November, 2011

Published in print edition November, 2011

Vasculogenesis is the process of new blood vessel formation during embryonic development of the cardiovascular system. This is followed by formation of a vascular tree and finally the cardiovascular system with the myriad of blood vessels that nourish all tissues and organs. Angiogenesis, on the other hand is the process by which new blood vessels take shape from existing blood vessels by "sprouting" of endothelial cells thus expanding the vascular tree. Both scenarios are based on activation, migration, proliferation and maturation of unique precursor cells. The study of blood vessel formation is an essential component of embryonic development, congenital malformations, degenerative diseases, inflammation and cancer and thus has widespread appeal to the biomedical field. Moreover, scientists are now harnessing this information for the purpose of building living blood vessel substitutes for replacement of diseased arteries and veins. This book highlights novel advances in the field of vasculogenesis and angiogenesis, including embryogenesis and development, regulation of progenitor cells, cancer and blood vessel regeneration. We consider this book a good initial source of information for graduate students, medical students and scientists interested in the intricacies of blood vessel formation, maturation, disease and replacement.

\title{
How to reference
}

In order to correctly reference this scholarly work, feel free to copy and paste the following:

Carla Costa (2011). Vasculogenesis in Diabetes-Associated Diseases: Unraveling the Diabetic Paradox, Vasculogenesis and Angiogenesis - from Embryonic Development to Regenerative Medicine, Dr. Dan Simionescu (Ed.), ISBN: 978-953-307-882-3, InTech, Available from:

http://www.intechopen.com/books/vasculogenesis-and-angiogenesis-from-embryonic-development-toregenerative-medicine/vasculogenesis-in-diabetes-associated-diseases-unraveling-the-diabetic-paradox

\section{INTECH}

open science | open minds

\author{
InTech Europe \\ University Campus STeP Ri \\ Slavka Krautzeka 83/A \\ 51000 Rijeka, Croatia \\ Phone: +385 (51) 770447 \\ Fax: +385 (51) 686166 \\ www.intechopen.com
}

\author{
InTech China \\ Unit 405, Office Block, Hotel Equatorial Shanghai \\ No.65, Yan An Road (West), Shanghai, 200040, China \\ 中国上海市延安西路65号上海国际贵都大饭店办公楼 405 单元 \\ Phone: +86-21-62489820 \\ Fax: +86-21-62489821
}


(C) 2011 The Author(s). Licensee IntechOpen. This is an open access article distributed under the terms of the Creative Commons Attribution 3.0 License, which permits unrestricted use, distribution, and reproduction in any medium, provided the original work is properly cited. 